ARTICLE

DOI: $10.1038 / s 41467-018-07062-8$

\title{
Organic bromine compounds produced in sea ice in Antarctic winter
}

\author{
Katarina Abrahamsson', Anna Granfors², Martin Ahnoff', Carlos A. Cuevas ${ }^{3} \&$ Alfonso Saiz-Lopez (1) ${ }^{3}$
}

During polar springtime, active bromine drives ozone, a greenhouse gas, to near-zero levels. Bromine production and emission in the polar regions have so far been assumed to require sunlight. Here, we report measurements of bromocarbons in sea ice, snow, and air during the Antarctic winter that reveal an unexpected new source of organic bromine to the atmosphere during periods of no sunlight. The results show that Antarctic winter sea ice provides 10 times more bromocarbons to the atmosphere than Southern Ocean waters, and substantially more than summer sea ice. The inclusion of these measurements in a global climate model indicates that the emitted bromocarbons will disperse throughout the troposphere in the southern hemisphere and through photochemical degradation to bromine atoms, contribute $\sim 10 \%$ to the tropospheric reactive bromine budget. Combined together, our results suggest that winter sea ice could potentially be an important source of atmospheric bromine with implications for atmospheric chemistry and climate at a hemispheric scale.

\footnotetext{
${ }^{1}$ Department of Marine Sciences, University of Gothenburg, Carl Skottbergs gata 22B, SE-41319 Gothenburg, Sweden. ${ }^{2}$ AstraZeneca, Product Technology and Development, SE-43183 Mölndal, Sweden. ${ }^{3}$ Department of Atmospheric Chemistry and Climate, Institute of Physical Chemistry Rocasolano, Serrano 119, 28006 Madrid, Spain. Correspondence and requests for materials should be addressed to K.A. (email: katarina.abrahamsson@gu.se) or to A.S.-L. (email: a.saiz@csic.es)
} 
B romine-containing organic compounds (bromocarbons) are ubiquitous in the oceans, and they are mainly formed by macro- and microalgae ${ }^{1}$. Of these naturally produced substances, bromoform $\left(\mathrm{CHBr}_{3}\right)$ is the best known, since it is the most abundant brominated organic. It is formed in enzymatic processes developed to protect algal cells of reactive oxygen species, such as hydrogen peroxide, formed during photosynthesis ${ }^{1,2}$. In addition, several other bromocarbons are formed, such as dibromomethane $\left(\mathrm{CH}_{2} \mathrm{Br}_{2}\right)$, dibromochloromethane $\left(\mathrm{CHBr}_{2} \mathrm{Cl}\right)$, and bromodichloromethane $\left(\mathrm{CHBrCl}_{2}\right)$, either directly through the same enzymatic pathway, or by nucleophilic substitution of $\mathrm{CHBr}_{3}$. In the atmosphere, bromocarbons are photochemically degraded to reactive bromine which initiate the depletion of ozone and mercury, a contaminant of global concern ${ }^{3-5}$. BrO, formed by the reaction of atmospheric $\mathrm{Br}$ atoms with $\mathrm{O}_{3}$, has an impact on the sulfur cycle through the oxidation of dimethyl sulfide (DMS), leading to a $18 \%$ reduction in the DMS burden and lifetime ${ }^{6}$. The $\mathrm{Br}$ atom is the dominant oxidizer in mercury depletion events in the polar atmosphere ${ }^{7}$. Reactive bromine from the decomposition of bromocarbons also contributes to the depletion of ozone in the lower stratosphere ${ }^{8}$. The interplay between the oceanic sources of bromocarbons and their atmospheric impacts has led to the suggestion that these compounds are a link between climate change and atmospheric ozone ${ }^{9}$.

Recently, it has been shown that variability in polar tropospheric bromine oxide $(\mathrm{BrO})$ levels is correlated with first year sea ice concentrations, through the production of halogens in sea ice regions ${ }^{10}$. Reactive bromine is anti-correlated with ozone, which suggests that the efficiency of halogen-driven polar tropospheric ozone depletion is related to sea ice dynamics and biogeochemical processes. Research on the role of sea ice in the formation of reactive halogens has in recent years mainly focused on the inorganic chemistry of saline surfaces, where sea-salt halides are oxidized to more reactive forms ${ }^{11,12}$. Similarly, inorganic bromine has also been shown to form in saline snow ${ }^{13}$. Arctic and Antarctic sea ice algae have been estimated to emit organo-bromine with $\sim 70-80 \times 10^{8} \mathrm{~g} \mathrm{yr}^{-1}$, suggesting that the produced compounds are released into seawater and then reach the atmosphere $^{14}$. Other investigations have pointed out the possibility of sea ice as a source of atmospheric $\mathrm{CHBr}_{3}$ in the Amundsen Sea (Antarctica) during the sunlit period ${ }^{15}$. In coastal Antarctica, concentrations of iodo-carbons in sea ice were found to be strongly enhanced relative to seawater, suggesting a significant local source within the sea ice ${ }^{16,17}$. Therefore, although halocarbons are thought to be produced within sea ice, two key questions remain unknown: (i) whether this source is significant in supplying bromocarbons to the atmosphere relative to the flux from the surface waters in leads and the open ocean, and (ii) the role of biogeochemical cycles of bromocarbons during polar winter, as their production, and thereby emissions, have so far been assumed to require sunlight.

In this work, we report profile measurements of bromocarbons in snow, sea ice, and air during Antarctic winter that represent a new source of atmospheric bromine during the polar night. We combine the observations with a state-of-the-art global chemistry-climate model. The results provide strong evidence that Antarctic winter sea ice is a significant source of bromocarbons, which spread and contribute to the burden of atmospheric bromine throughout the southern hemisphere.

\section{Results}

Bromocarbon concentrations in Antarctic winter. A field campaign was performed from 8 June to 12 August 2013 in the Weddell Sea, Antarctica (Supplementary Figure 1). Here we report data from the dark period of the cruise 17 June to the 15 July. The concentrations of bromocarbons $\left(\mathrm{CHBr}_{3}, \mathrm{CH}_{2} \mathrm{Br}_{2}\right.$, $\mathrm{CHBr}_{2} \mathrm{Cl}$, and $\mathrm{CHBrCl}_{2}$ ) were measured in snow, sea ice, and air to estimate their source strength of seasonal sea ice in the absence of sunlight (Fig. 1). These measurements were made at nine stations where 23 ice cores were collected. The thickness of the first year sea ice over which measurements were made varied between 43 and $118 \mathrm{~cm}$, whereas the snow thickness varied between zero and 5-40 cm (Supplementary Table 1).

The air measurements (located at $20 \mathrm{~m}$ above sea ice level) revealed unexpectedly high concentrations of bromocarbons under conditions of solar zenith angle (SZA) larger than $90^{\circ}$ (i.e., full darkness), with average values of $9.5 \mathrm{pptv}\left(\mathrm{CHBr}_{3}\right), 0.53$ pptv $\left(\mathrm{CHBrCl}_{2}\right), 0.91$ pptv $\left(\mathrm{CHBr}_{2} \mathrm{Cl}\right)$, and 1.2 pptv for $\mathrm{CH}_{2} \mathrm{Br}_{2}$ (Fig. 1). As a comparison, studies of bromocarbons in air in the Arctic region before polar sunrise measured concentrations of $\mathrm{CHBr}_{3}, \mathrm{CHBrCl}_{2}, \mathrm{CHBr}_{2} \mathrm{Cl}$, and $\mathrm{CH}_{2} \mathrm{Br}_{2}$ to be 2.6, not detected, 0.3 and $0.8 \mathrm{pptv}$, respectively. After sunrise, the concentrations dropped by half for $\mathrm{CHBr}_{3}$, whereas the concentrations remained fairly constant for the other compounds ${ }^{18}$. Compared with observations made in the summertime in the Southern Ocean $^{15,19}$, the average winter air concentration of bromoform was ca. 10 times higher. Similarly, the maximum concentration of $\mathrm{CH}_{2} \mathrm{Br}_{2}$ found in winter was 2.9 pptv compared with 1.4 during summer and that of $\mathrm{CHBr}_{2} \mathrm{Cl}$ was 2.5 pptv in summer ${ }^{19}$. The boundary layer in Antarctica during winter is much lower than over open ocean ${ }^{20}$, therefore these bromocarbon fluxes could lead to lower air concentrations under higher boundary layer height conditions. The variations in concentration were not related to wind direction. Backward air mass trajectories revealed that the dominant wind direction was from West and South (Supplementary Figure 1). We note that the highest air concentrations occurred at low wind speeds $\left(<6 \mathrm{~m} \mathrm{~s}^{-1}\right)$ (Fig. 1) associated with stable shallow boundary layers ${ }^{20}$.

In addition to the air observations, sharp concentration gradients in the vertical profiles of bromocarbons in sea ice and snow were observed, with highest values at the ice-snow interface (Fig. 2, Supplementary Figure 2). This implies that the observed bromocarbons were formed at the interface and diffused out of the snow. Sharp concentration gradients have previously been observed in Arctic sea ice during spring with similar distribution patterns in sea ice ${ }^{21}$ and snow $^{22}$. Note that on one location (Station 500) one of the coring sites was flooded, which led to slightly different profiles, as indicated by the high salinity found close to the sea ice interface (Supplementary Figure 2, Supplementary Table 2-3). The highest concentrations found at the interface during the Antarctic winter were 1200, 1100, 270, and $18000 \mathrm{pM}$ for $\mathrm{CH}_{2} \mathrm{Br}_{2}, \mathrm{CHBr}_{2} \mathrm{Cl}, \mathrm{CHBrCl}_{2}$, and $\mathrm{CHBr}_{3}$, respectively (Fig. 1), which can be compared with summer sea ice maximum values of $90,14,42$, and $420 \mathrm{pM}$, respectively ${ }^{23}$. During summer, the depth profiles differed with bromocarbon concentrations varying to a large extent with chlorophyll- $\mathrm{a}^{23}$.The complete set of air, snow, and sea ice concentrations for all stations, salinity, temperature, and brine volume data are given in Supplementary Tables 2-4. Together with the air observations, the measured profiles across snow and sea ice show that bromocarbons are produced locally in the Antarctic winter sea ice.

\section{Discussion}

We now turn to the mechanism behind the observed production of bromocarbons in winter sea ice. The natural formation of bromocarbons has previously been demonstrated to be light dependent $^{2}$, and include enzymatic pathways that rid cells of reactive oxygen species formed mainly during photosynthesis. 

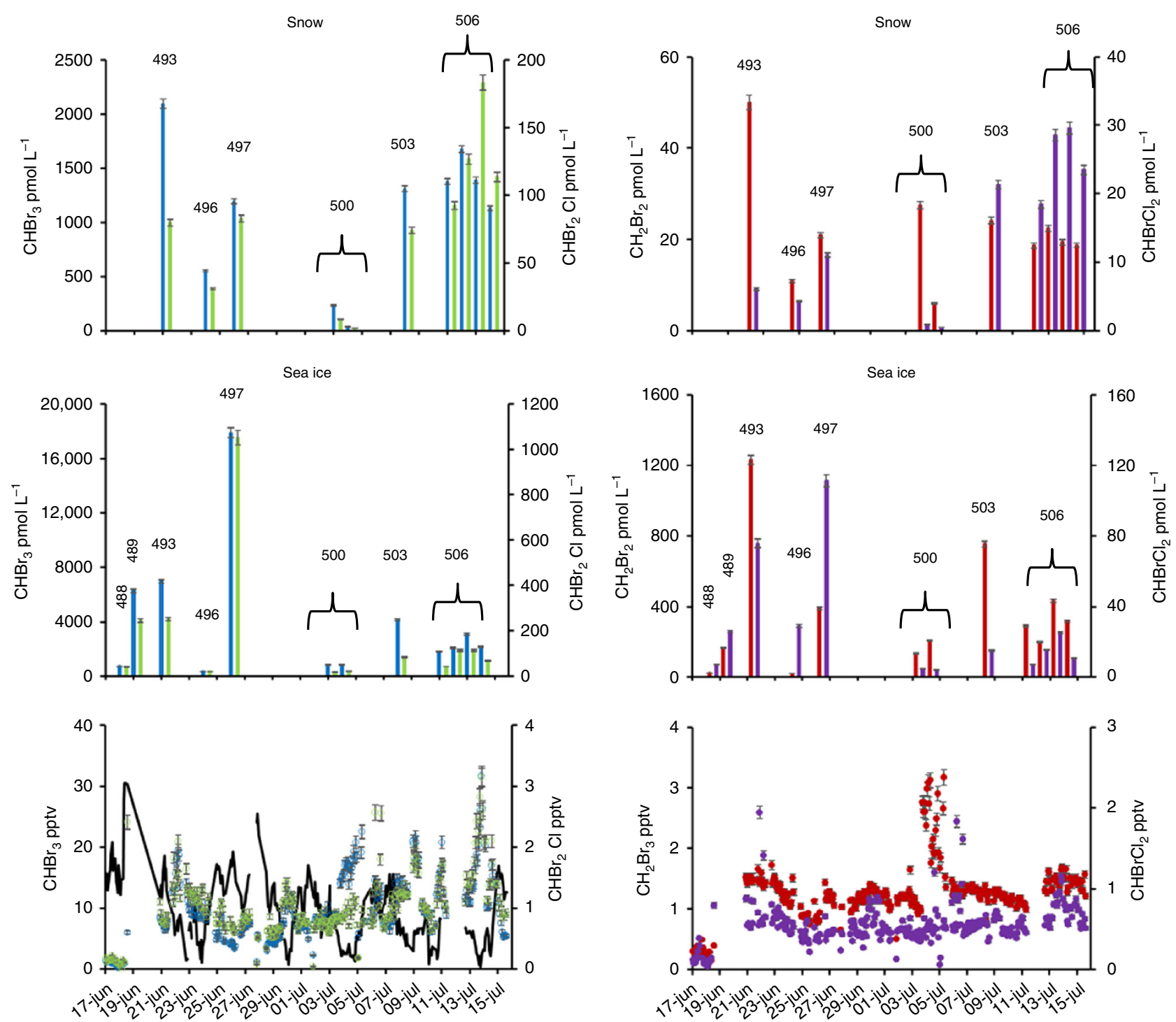

Fig. 1 Time series of sea ice, snow, and air measurements of bromocarbons during the Antarctic winter in 2013. From top to bottom: snow, sea ice and air measurements of $\mathrm{CHBr}_{3}$ (blue), $\mathrm{CHBr}_{2} \mathrm{Cl}$ (green), $\mathrm{CH}_{2} \mathrm{Br}_{2}$ (red), and $\mathrm{CHBrCl}_{2}$ (purple). Wind speed (black line) is shown in bottom panel. At stations 496, 500, and 506 duplicate ice cores were sampled, and the average values are presented. In total, 23 ice cores and 30 snow samples were analyzed. Time resolution of measurements in air was 40 min. For geographical location of stations see Supplementary Table 1 and Supplementary Figure 1. The error bars relates to the instrumental errors

The reduction of hydrogen peroxide by haloperoxidases results in the formation of hypohalous acids, such as $\mathrm{HOBr}$, which subsequently reacts with dissolved organic matter, forming bromocarbons $^{24}$. Laboratory experiments have shown that there is an abiotic pathway for $\mathrm{HOBr}$ production through the reaction of ozone with bromide that occurs in darkness ${ }^{25}$. This proceeds via ozone deposition to the ice surface followed by oxidation of bromide. On ice surfaces, a disordered layer of molecules exist, which has been shown to favor halogen interactions. Also, the freezing of seawater enhances the ionic strength that leads to enhanced rates of chemical reactions ${ }^{26}$. Recent investigations have shown that the oxidation of bromide by ozone involves the formation of the intermediate ozonide $\mathrm{Br} \cdot \mathrm{OOO}^{-}$in aqueous bulk solution with a preference for the liquid-gas interface, and the authors conclude that the oxidation of bromide on surfaces plays a more important role than previously thought ${ }^{27}$.

Subsequently, a number of different organic compounds such as ketones, phenols, alkenes etc., can react with $\mathrm{HOBr}$ to form bromocarbons ${ }^{28}$. Therefore, the differences in organo-bromine concentrations found in our ice cores can be due to differences in composition of the organic compounds being brominated. The similarities in depth profiles within the sea ice between the individual bromocarbon indicate similar formation mechanisms for all four investigated bromocarbons.

Micro-organisms could also be responsible for the bromocarbon production, as they have been shown to be active in sea ice during winter ${ }^{29,30}$. For instance, if the enzymatic pathways are active, the stress caused by the measured high salinity at the ice interface, low temperatures, and/or inclusion in the ice lattice could increase the production, and contribute to the high concentrations of bromocarbons found at the snow/ice interface. Hence, although little is known about how bromocarbons form under darkness; our results provide a strong case, for the first time, that first year Antarctic sea ice has extremely high bromocarbon concentrations at a period with no sunlight.

Next, the magnitude of the release of individual bromocarbons from the ice surface to the atmosphere was calculated based on the assumption that the bromocarbons were formed on the 

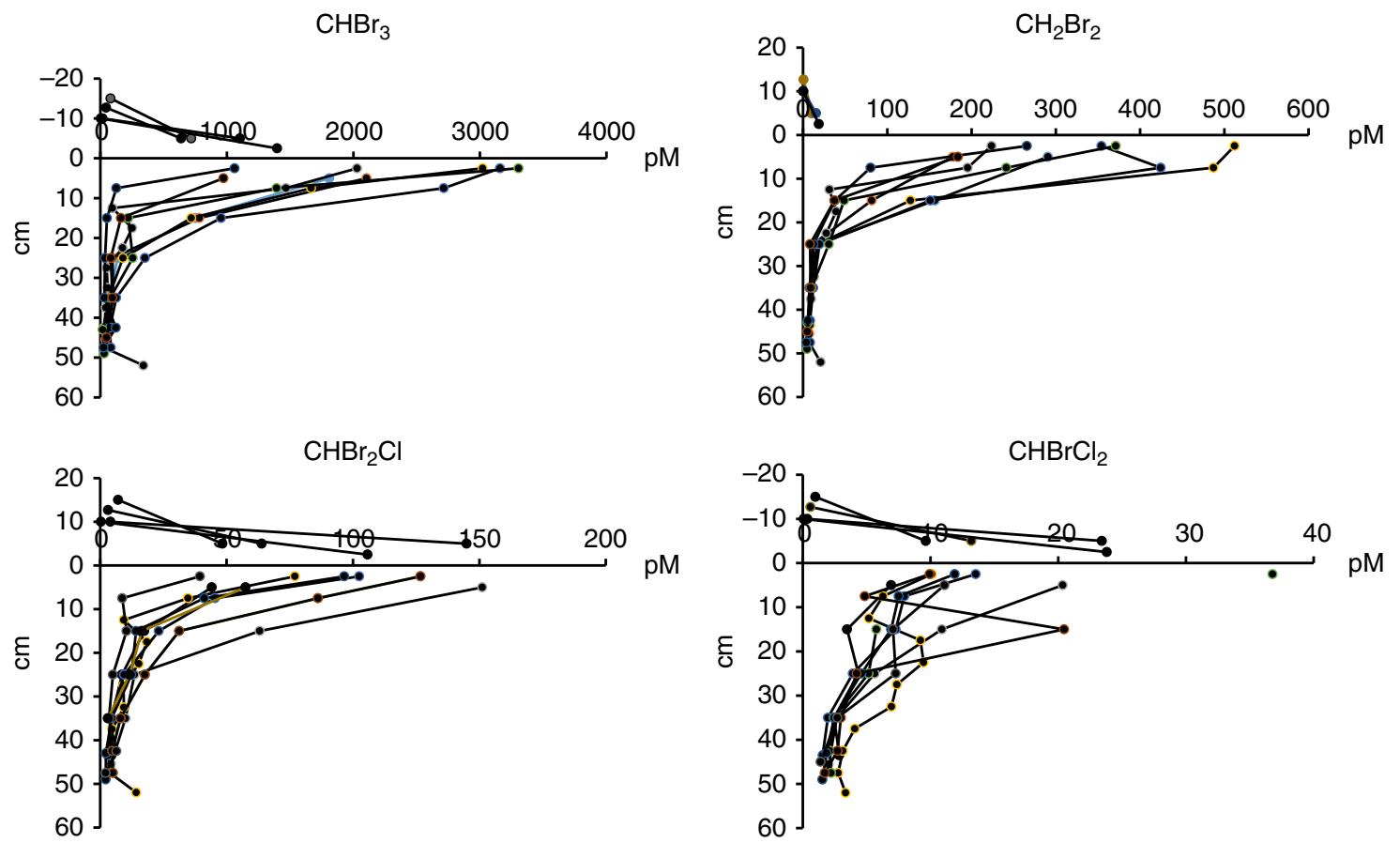

Fig. 2 Profiles of brominated halocarbons $\left(\mathrm{CHBr}_{3}, \mathrm{CH}_{2} \mathrm{Br}_{2}, \mathrm{CHBr}_{2} \mathrm{Cl}\right.$, and $\left.\mathrm{CHBrCl}_{2}\right)$ in sea ice and snow. Data from station 506 include eight sea ice core profiles and four snow profiles. The line at $\mathrm{O} \mathrm{cm}$ indicates the sea ice-snow interface. The total snow depth was $17 \mathrm{~cm}$. The complete concentration data set is found in Supplementary Tables 3-5

surface of sea ice and subsequently diffused through the snow to the atmosphere. The interstitial air concentrations were calculated from the concentrations found in melted snow, the fraction of water and air, respectively, and the Henry's law constants (Methods). We found the concentration gradient in snow to decrease linearly (Fig. 2, Supplementary Table 4). Adsorption and desorption studies of halocarbons (i.e., $\mathrm{CHCl}_{3}$ and $\mathrm{CHBr}_{3}$ ) on ice revealed that $\mathrm{CHBr}_{3}$ is mobile at temperatures as low as $85 \mathrm{~K}$, which allows us to infer that the bromocarbons were not adsorbed/desorbed on snow surfaces.

It has been shown that wind pumping could be important for the flux of gases through the snow. In such cases, concentration gradients are absent and the fluxes are not governed by diffusive processes $^{31}$. As our results show the presence of concentration gradients that could be assigned to diffusive processes, a simplified diffusion calculation was performed using the molecular diffusivities in air (Methods). These diffusivities are comparable to the effective diffusivities calculated for $\mathrm{SF}_{6}$ in snow at Summit, Greenland ${ }^{32}$. The median ice-snow-air fluxes of individual halocarbons varied between 1 and $50 \mathrm{nmol} \mathrm{m}^{-2} \mathrm{~h}^{-1}$ (Table 1). We performed a one sample Wilcoxon signed rank test that shows that the median "fluxes" are higher than $16 \mathrm{nmol} \mathrm{m}^{-2} \mathrm{~h}^{-1}$ $\left(\mathrm{CHBr}_{3}\right) ; \quad 0.5 \mathrm{nmol} \mathrm{m}^{-2} \mathrm{~h}^{-1} \quad\left(\mathrm{CH}_{2} \mathrm{Br}_{2}\right) ; \quad 0.3 \mathrm{nmol} \mathrm{m}^{-2} \mathrm{~h}^{-1}$ $\left(\mathrm{CHBrCl}_{2}\right.$ and $0.5 \mathrm{nmol} \mathrm{m}^{-2} \mathrm{~h}^{-1}\left(\mathrm{CHBr}_{2} \mathrm{Cl}\right)$ at a significance level of 0.05 . Fluxes from all stations are given in Supplementary Table 5. The total error of the individual fluxes was estimated to be $13 \%$ based on the measurement uncertainties in concentrations and in the snow depth measurements.

On board, attempts were made to perform an air gradient flux estimate. There were some indications that the air concentration just above the snow had elevated concentrations compared with a height of 2.2 or $20 \mathrm{~m}$ (Supplementary Figure 3). However, the precision of our analytical method was not good enough to use the sometimes small differences in concentrations for flux calculations. Also, there was no possibility to take into consideration the influence of the ship on the air movement. Eddy covariance or
Table 1 Estimated flux of bromocarbons from sea ice

\begin{tabular}{|c|c|c|}
\hline & $\begin{array}{l}\text { Flux }\left(\mathrm{nmol} \mathrm{m}^{-2} \mathbf{h}^{-1}\right) \\
\text { stations without snow }\end{array}$ & $\begin{array}{l}\text { Flux }\left(\mathrm{nmol} \mathrm{m} \mathrm{m}^{-2} \mathrm{~h}^{-1}\right) \text { stations } \\
\text { with snow }(n=9)\end{array}$ \\
\hline $\begin{array}{l}\mathrm{CH}_{2} \mathrm{Br}_{2} \\
\text { Range } \\
\text { Median }\end{array}$ & $20 ; 50$ & $\begin{array}{l}0.5-7 \\
2\end{array}$ \\
\hline $\begin{array}{l}\mathrm{CHBrCl}_{2} \\
\text { Range } \\
\text { Median } \\
\mathrm{CHBr}_{2} \mathrm{Cl}\end{array}$ & $3 ; 5$ & $0.1-8$ \\
\hline median & $50 ; 70$ & $\begin{array}{l}0.5-8 \\
2\end{array}$ \\
\hline $\begin{array}{l}\mathrm{CHBr}_{3} \\
\text { Range } \\
\text { Median }\end{array}$ & $800 ; 1700$ & $\begin{array}{l}8-200 \\
50\end{array}$ \\
\hline
\end{tabular}

air gradient flux measurements depend on the capability of rapid measurements at relevant concentrations. In our case, the concentrations are low $(0.5-30 \mathrm{pptv})$ and required sample pretreatment. The variations in concentrations during the above described measurements are exemplified in Supplementary Figure 3. At station 506 the concentrations of $\mathrm{CHBr}_{3}$ varied between 20 and 100 pptv with the highest values at midnight. These variations were related to wind speed. Around midnight the wind speed dropped from ca $7 \mathrm{~m} \mathrm{~s}^{-1}$ to ca $1 \mathrm{~m} \mathrm{~s}^{-1}$ to, later in the night, increase again to ca $9 \mathrm{~m} \mathrm{~s}^{-1}$. This trend was valid for all bromocarbons (positive linear regression between bromocarbons with $R^{2}$ values of 0.7 ).

As no earlier attempts have been made to estimate the flux of bromocarbons from sea ice surfaces through snow to the atmosphere we here performed calculations using an established 
method for calculating sea-air fluxes, utilizing the upper most sea ice values instead of seawater concentrations and the air concentrations measured in the snow closest to the ice surface. For stations 488 and 489 that did not have any snow cover (Table 1) we used the measured wind speed. We found that the two methods (Methods) produced median values of flux estimates in the same order of magnitude at the stations where multiple cores were sampled (Supplementary Table 5). This fact could be seen as an indirect evidence that the flux through snow could be sustained by the sea ice surface. In Fig. 1, the snow concentrations could be compared with the upper most layer of the sea ice. In general, the higher the concentration in sea ice the higher the values in snow (Supplementary Tables 2-3, Fig. 2 and Supplementary Figure 2). A principal component analysis (Supplementary Figure 4) also reveals that the highest concentrations of bromocarbons were found in the upper most part of the core and in the snow closest to the ice. The variability in sea ice is known to be one major obstacle for extrapolating physical, chemical, and biological properties. On kilometer scales, it can be concluded that the distribution pattern was consistent in the seasonal ice. However, there was a large variation in the concentrations of individual bromocarbons in snow and surface sea ice, which was reflected in the calculated fluxes which varied with one order of magnitude. The variability on meter scales showed less variation (Supplementary Table 5). The snow concentrations were clearly linked to the surface concentrations in sea ice (Fig.1), and thereby the magnitude of the flux. At station 500, where parts of the flow were flooded, the lowest concentrations were found and also the lowest flux. Predicted global sea to air fluxes of $\mathrm{CHBr}_{3}$ and $\mathrm{CH}_{2} \mathrm{Br}_{2}$ in the Southern Ocean are lower than our ice-snow-air fluxes by several orders of magnitude ${ }^{33}$. This demonstrates that areas covered with seasonal ice are potential foci for bromocarbon emissions to the atmosphere, even in the absence of sunlight. Figure 3 depicts a simplified schematic of the ice-snow-air interface and the suggested release mechanisms of organic bromine from Antarctic winter sea ice to the atmosphere.

We now use a state-of-the-art global chemistry-climate mode $^{34,35}$ constrained with the observed bromocarbons fluxes during the period of measurements and over Antarctic first year sea ice (Methods). The results show an accumulation of brominated halocarbons in the atmosphere during the polar winter until the austral sunrise in August when photodecomposition starts to reduce the bromocarbon concentrations (Fig. 4, Supplementary Figures 5, 6, 7). Remarkably, since bromocarbons are relatively long-lived (weeks to months) the winter sea ice emission combined with atmospheric transport results in the distribution of these species throughout the troposphere over the entire southern hemisphere (Fig. 4). The model driven by the

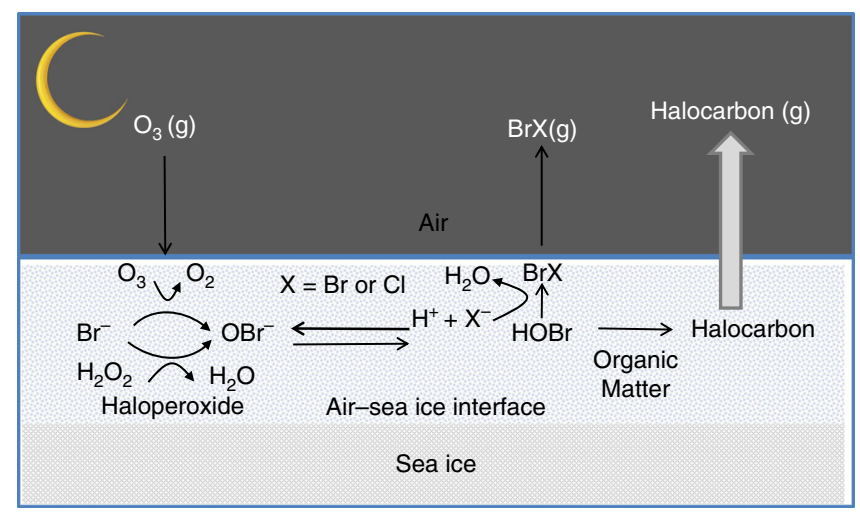

Fig. 3 Schematic of the possible release mechanisms of bromocarbons from sea ice in the Antarctic winter observed ice-snow atmosphere bromocarbon fluxes satisfactorily simulates the range of measured surface air concentrations of organo-bromine species (Table 2 and Supplementary Figure 8).

In the austral spring, the arrival of sunlight initiates the photochemical breakdown of bromocarbons, accumulated during the polar night, leading to the formation of reactive inorganic bromine species throughout the troposphere of the southern hemisphere (Supplementary Figures 9, 10, 11). Increases of $1 \mathrm{pptv}$ of active bromine are simulated up to the mid- to uppertroposphere over large regions of the southern hemisphere, far away from the Antarctic sea ice source region, i.e., $80^{\circ}-30^{\circ} \mathrm{S}$ (Supplementary Figure 9). We calculated that integrated over the southern hemisphere, the polar night emission of organic bromine during the period of measurements results in an increase of $\sim 10 \%$ of tropospheric reactive bromine $\left(\mathrm{Br}, \mathrm{Br}_{2}, \mathrm{BrO}, \mathrm{HBr}\right.$, $\left.\mathrm{HOBr}, \mathrm{BrONO}_{2}, \mathrm{BrCl}\right)^{36}$, based on the average emission fluxes of bromocarbons from Table 1 (Flux in stations with snow). For the lower and upper limits of bromocarbon emission fluxes (Table 1), the increase in tropospheric reactive bromine is $1.5 \%$ and $31 \%$, respectively. This can be considered a lower limit since a sustained emission during the whole polar night and sunlit periods (which are not currently considered in chemistry-climate models) could have larger hemispheric impacts on the levels of reactive bromine in the atmosphere.

A final point to consider is the geographical scale of emissions. The Antarctic sea ice cover in winter is $\sim 19 \times 10^{6} \mathrm{~km}^{2}$. If we use this area in combination with the range of fluxes given in Table 1, the flux of bromocarbons to the atmosphere would range from of 0.6-1.8 Gmol Br per month of polar night, which should be compared with the estimated global contribution of $2.4-3.5 \mathrm{Gmol}$ $\mathrm{Bry}^{-1}$ based on $\mathrm{CHBr}_{3}$ and $\mathrm{CH}_{2} \mathrm{Br}_{2}{ }^{33}$. The model calculations indicate that the winter emissions of bromocarbons spread throughout the southern hemisphere, and due to their relatively long lifetime they could even be transported to the stratosphere.

In summary, this study underscores that a large source of bromine from winter sea ice is currently neglected in climate models. The relatively long atmospheric lifetime of Antarctic winter sea ice-emitted bromocarbons allows their transport to lower latitudes and even to the stratosphere, adding to the global atmospheric bromine burden. Consideration of this new source of polar bromine requires re-assessment of the bromine-mediated impacts on the global tropospheric ozone budget and mercury deposition.

\section{Methods}

Halocarbon measurements. Data were collected during the ANTXXIX/6 expedition conducted during austral winter aboard the R.V Polarstern from 8 June to 12 August 2013 in the Weddell Sea (Supplementary Figure 1). Samples of ice, snow, and brine, were collected at nine different stations, during the dark period of the cruise (Supplementary Table 1). At stations 500 and 506, multiple samples were collected over two or more days. A Mark II coring system from Kovacs Enterprise with a diameter of $0.09 \mathrm{~m}$ made out of a light weight filament wound composite tube with plastic fitting was used. Ice cores were divided into $10 \mathrm{~cm}$ or $5 \mathrm{~cm}$ sections and individually packed in gas-tight Tedlar $^{\mathrm{TM}}$ bags. The air surrounding the sample was removed from the bags using a manual pump according to Granfors et al. ${ }^{23}$. The ice samples were thawed in darkness at room temperature for $\sim 24 \mathrm{~h}$. Snow samples were collected as close as possible to the ice coring site (maximum distance ca $10 \mathrm{~m}$ ) and divided into $5-10 \mathrm{~cm}$ sections, individually packed in gas-tight Tedlar@ bags. The snow samples were thawed in darkness at room temperature for $\sim 12 \mathrm{~h}$. The halocarbon compounds $\mathrm{CHBr}_{3}, \mathrm{CH}_{2} \mathrm{Br}_{2}$, $\mathrm{CHCl}_{2} \mathrm{Br}$, and $\mathrm{CHClBr}_{2}$ were quantified. They were pre-concentrated using three purge-and-trap systems: Velocity XPT (Teledyne Tekmar) connected to an autosampler (AQUATek70, Teledyne Tekmar), and two custom-made purge-and-trap system, which were coupled to gas chromatographs with electron capture detection (Varian 3800), according to the methods described by Mattsson et al. ${ }^{15}$. One of the custom-made purge-and-trap instruments (custom-made system 1 Supplementary Table 6) was equipped for air sample analysis in addition to water sample analysis. Air was continuously drawn through a $100 \mathrm{~m}, 4 \mathrm{~mm}$ inner diameter, Teflon tube by an air pump located downstream from the sampling loop. This instrument was also fed with a continuous stream of water from the ship's surface water inlet. The 

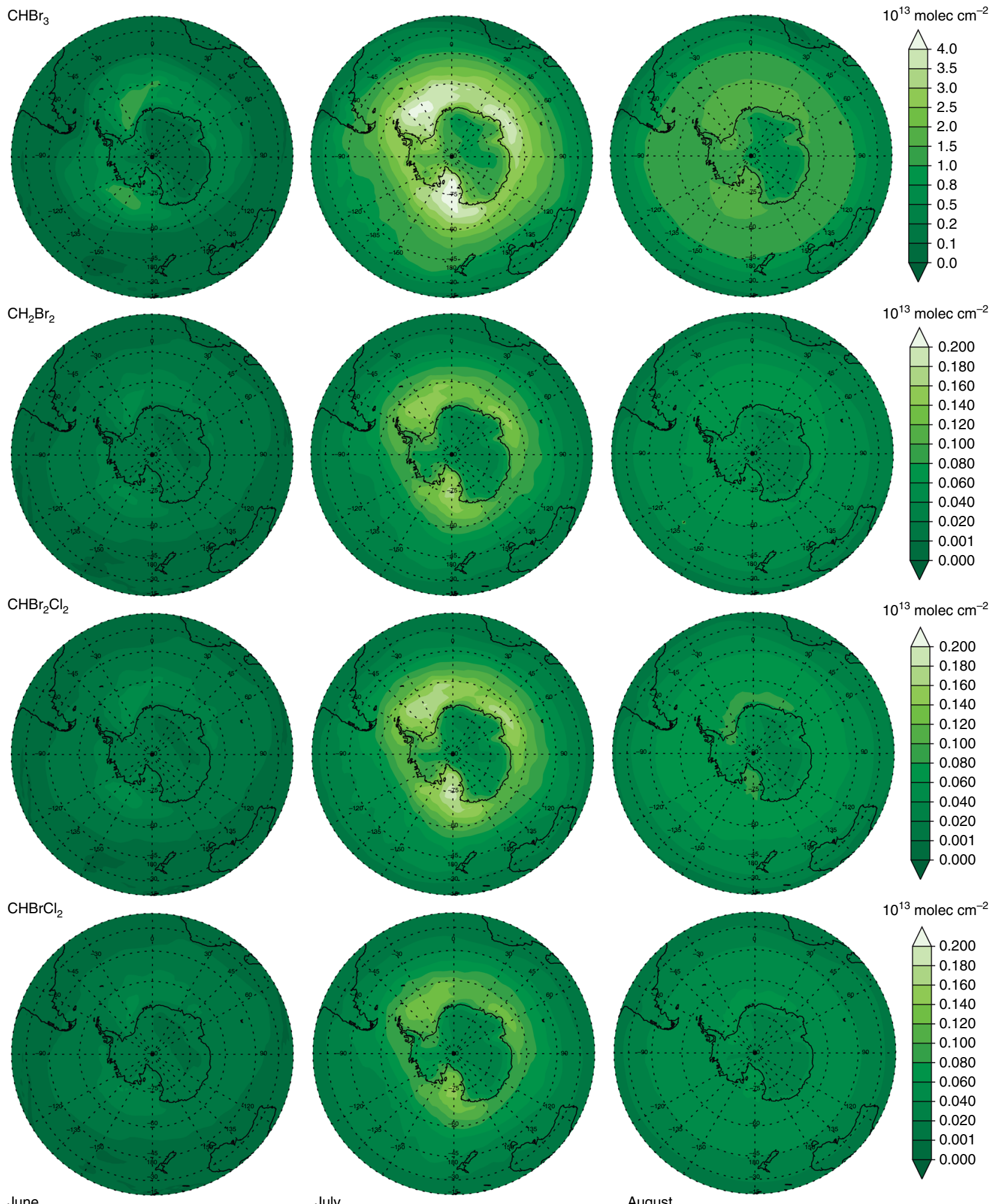

Fig. 4 Modeled distribution of monthly averaged tropospheric $\left(\mathrm{CHBr}_{3}, \mathrm{CH}_{2} \mathrm{Br}_{2}, \mathrm{CHBr}_{2} \mathrm{Cl}\right.$, and $\left.\mathrm{CHBrCl}_{2}\right)$ over the Southern Hemisphere. This spatial distribution is the result of sea ice emissions of bromocarbons during the Antarctic winter using the averaged fluxes of bromocarbons from Table 1 (flux in stations with snow)

system was set up to automatically alternate between water and air sampling. The systems were calibrated with external standards of $\mathrm{CH}_{2} \mathrm{Br}_{2}$ (Merck, 99\%), $\mathrm{CHBrCl}_{2}$ (Fluka, > 98\%), $\mathrm{CH}_{2} \mathrm{ClI}$ (Fluka, >97\%), $\mathrm{CHBr}_{2} \mathrm{Cl}$ (Fluka, >97\%), and $\mathrm{CHBr}_{3}$ (Merck, $>98 \%$ ) diluted from stock solutions in methanol (Sigma-Aldrich, suitable for purge-and trap analysis) in seawater to give final concentrations in the picomolar range in the purge chamber. The same standard solutions were used for calibration of air measurements. The detection limits of the systems are given in Supplementary Table 6. The overall repeatability for individual compounds was between $1 \%$ and $5 \%$. The three instruments were inter-calibrated using standards as well as samples with high and low concentrations of the compounds. 


\section{Table 2 Measured and modeled surface air bromocarbon concentrations}

\begin{tabular}{|c|c|c|}
\hline Bromocarbon species & $\begin{array}{l}\text { Measured range/ } \\
\text { pptv }\end{array}$ & $\begin{array}{l}\text { Modeled range/ } \\
\text { pptv }\end{array}$ \\
\hline $\mathrm{CHBr}_{3}$ & nd-32 & $0.2-40$ \\
\hline $\mathrm{CHBr}_{2} \mathrm{Cl}$ & $0.1-3.2$ & $0.1-1.8$ \\
\hline $\mathrm{CH}_{2} \mathrm{Br}_{2}$ & $0.3-3.2$ & $0.9-2.3$ \\
\hline $\mathrm{CHBrCl}_{2}$ & $0.1-1.9$ & $0.1-1.4$ \\
\hline
\end{tabular}

The modeled values correspond to a layer 0-200 $\mathrm{m}$. Altitude for the same date and location of the measurements

Sea ice temperatures were measured immediately after the ice core was recovered at $10 \mathrm{~cm}$ intervals using a digital thermistor, Amadigit, resolution $0.1{ }^{\circ} \mathrm{C}$ (summer expedition) and a high precision RTD thermometer with a Pt100 temperature sensor with an accuracy of $\pm 0.1^{\circ} \mathrm{C}$ (winter expedition). Salinity and conductivity of the melted sea ice were measured using a conductivity meter, WTWCond330i or 3210, with a precision and accuracy of \pm 0.1 .

Brine volume $\left(v_{b}\right)$ was derived from ice temperature $\left(T_{\mathrm{i}}\right)$ and bulk salinity $\left(S_{\mathrm{i}}\right)$ according to the equation of Frankenstein and Garner [1967] ${ }^{37}$ (Eq. 1).

$$
v_{\mathrm{b}}=S_{\mathrm{i}}\left(0.0532-4.919 / T_{\mathrm{i}}\right)
$$

For presentation of the vertical distribution of halocarbons in sea ice, halocarbon concentrations in bulk ice were divided by the brine volume calculated for each sample. This brine normalized concentration represents the estimated concentration of halocarbons in the sea ice brine.

Flux calculations. Stations $493-506$ had a snow cover of 5-40 cm. Vertical profiles in snow (thickness $>10 \mathrm{~cm}$ ) indicated that the snow was ventilated above this level. The interstitial air concentrations were calculated from the measured concentrations in melted snow, the volume of air and water in the samples and the Henry's law constant at ambient temperature. The linearly decreasing concentrations in snow along with the following air diffusion coefficients were used to calculate fluxes according to Fick's first law (Eq. 2) $\left(\mathrm{CHBr}_{3} 0.0149 ; \mathrm{CH}_{2} \mathrm{Br}_{2} \quad 0.0287 ; \mathrm{CHBrCl}_{2}\right.$ $\left.0.0298 ; \mathrm{CHBr}_{2} \mathrm{Cl} 0.0196 \mathrm{~cm}^{2} \mathrm{~s}^{-1}\right)$

$$
\text { Flux }=\Delta[X]_{\mathrm{air}} \times D_{\mathrm{a}} / z
$$

where $[X]$ is the individual concentration of bromocarbons, $D_{a}$ the molecular diffusivity and $z$ is the snow depth.

To compare, fluxes were also derived using a sea-air flux model according to Waninkoff and McGillis ${ }^{38}$. The Schmidt numbers were calculated based on brine salinities and ice surface temperatures ${ }^{39}$. Henry's law constants were calculated according to Moore et al. ${ }^{40}$. The air concentrations used in the calculations were those from the air measured in snow closest to the ice surface. This exercise yielded median fluxes of the bromocarbons $\mathrm{CHBr}_{3}, \mathrm{CH}_{2} \mathrm{Br}_{2}, \mathrm{CHCl}_{2} \mathrm{Br}$, and $\mathrm{CHClBr}_{2}$ of 70 , $15,0.4$, and $4 \mathrm{nmol} \mathrm{m}^{-2} \mathrm{~h}^{-}$respectively.

The CAM-Chem model. The model employed in this work is the global 3-D chemistry-climate model CAM-Chem (Community Atmospheric Model with chemistry, version 4.0) to assess the impact of the measured bromocarbons emissions upon the distribution of bromocarbons and reactive bromine throughout the southern hemisphere. The model includes a comprehensive chemistry scheme to simulate the evolution of trace gases and aerosols in the troposphere and the stratosphere ${ }^{34}$. The model runs with the iodine and bromine chemistry schemes from previous studies ${ }^{36,41-43}$, including the photochemical breakdown of bromoand iodo-carbons emitted from the oceans ${ }^{35}$ and abiotic oceanic sources of HOI and $\mathrm{I}_{2}{ }^{44}$. For this work, emissions of $\mathrm{CHBr}_{3}, \mathrm{CH}_{2} \mathrm{Br}_{2}, \mathrm{CHBr}_{2} \mathrm{Cl}$, and $\mathrm{CHBrCl}_{2}$ from Antarctic first year sea ice at SZA higher than $90^{\circ}$ have been implemented, according to measured fluxes. These emissions are only active during the campaign time period (18 June to 14 July), as a linear function of first year sea ice fraction. CAM-Chem has been configured in this work with a horizontal resolution of $1.9^{\circ}$ latitude by $2.5^{\circ}$ longitude and 26 vertical levels, from the surface to $\sim 40 \mathrm{~km}$ altitude. All model runs in this study were performed in the specified dynamics mode ${ }^{34}$ using offline meteorological fields instead of an online calculation, to allow direct comparisons between different simulations. This offline meteorology consists of a high-frequency meteorological input from a previous free running climatic simulation. The MERRA reanalysis data $\operatorname{set}^{45}$ is used in the model to supply the implemented sea ice fields.

\section{Data availability}

The code and data that support the findings of this study are available upon request.

Received: 27 October 2017 Accepted: 8 October 2018

Published online: 11 December 2018

\section{References}

1. Quack, B. \& Wallace, D. W. R. Air-sea flux of bromoform: controls, rates, and implications. Glob. Biogeochem. Cycles 17, 1023 (2003).

2. Collén, J., Ekdahl, A., Abrahamsson, K. \& Pedersén, M. The involvement of hydrogen peroxide in the production of volatile halogenated compounds by Meristiella gelidium. Phytochemistry 36, 1197-1202 (1994).

3. Montzka SA, Reimann S. Ozone-depleting substances (ODSs) and related chemicals. In: Scientific Assessment of Ozone Depletion: 2010, Global Research and Monitoring Project-Report No. 52. WMO (World Meteorological Organization, 2011).

4. WMO. World Meteorological Organization (WMO). Global Ozone Research and Monitoring Project-Report No. 56 (Geneva, Switzerland, 2014).

5. Saiz-Lopez, A. \& von Glasow, R. Reactive halogen chemistry in the troposphere. Chem. Soc. Rev. 41, 6448-6472 (2012).

6. Breider, T. J., Chipperfield, M. P., Richards, N. A. D., Carslaw, K. S., Mann, G. W. \& Spracklen, D. V. Impact of BrO on dimethylsulfide in the remote marine boundary layer. Geophys Res Lett. 37, 6 (2010).

7. Stephens, C. R. et al. The relative importance of chlorine and bromine radicals in the oxidation of atmospheric mercury at Barrow, Alaska. J. Geophys Res 117, 16 (2012).

8. Salawitch, R. J. et al. Sensitivity of ozone to bromine in the lower stratosphere Geophys Res Lett. 32, doi: 10.1029/2004GL021504 (2005).

9. Salawitch, R. J. Atmospheric chemistry: biogenic bromine. Nature 439, 275-277 (2006).

10. Simpson, W. R. et al. First-year sea-ice contact predicts bromine monoxide (BrO) levels at Barrow, Alaska better than potential frost flower contact. Atmos. Chem. Phys. 7, 621-627 (2007).

11. Simpson, W. R. et al. Halogens and their role in polar boundary-layer ozone depletion. Atmos. Chem. Phys. 7, 4375-4418 (2007).

12. Abbatt, J. P. D. et al. Halogen activation via interactions with environmental ice and snow in the polar lower troposphere and other regions. Atmos. Chem. Phys. 12, 6237-6271 (2012).

13. Pratt, K. A. et al. Photochemical production of molecular bromine in Arctic surface snowpacks. Nat. Geosci. 6, 351-356 (2013).

14. Sturges, W. T., Cota, G. F. \& Buckley, P. T. Bromoform emission from Arctic ice algae. Nature 358, 660-662 (1992).

15. Mattson, E., Karlsson, A., Smith, J. W. O. \& Abrahamsson, K. The relationship between biophysical variables and halocarbon distributions in the waters of the Amundsen and Ross Seas, Antarctica. Mar. Chem. 140-141, 1-9 (2012).

16. Granfors, A., Ahnoff, M., Mills, M. M. \& Abrahamsson, K. Organic iodine in Antarctic sea ice: a comparison between winter in the Weddell Sea and summer in the Amundsen Sea. J. Geophys. Res. 119, 2276-2291 (2014).

17. Atkinson, H. M. et al. Iodine emissions from the sea ice of the Weddell Sea. Atmos. Chem. Phys. 12, 11229-11244 (2012).

18. Yokouchi, Y., Akimoto, H., Barrie, L. A., Bottenheim, J. W., Anlauf, K. \& Jobson, B. T. Serial gas chromatographic/mass spectrometric measurements of some volatile organic compounds in the Arctic atmosphere during the 1992 Polar Sunrise Experiment. J. Geophys. Res. 99, 25379-25389 (1994).

19. Yokouchi, Y. et al. Correlations and emission ratios among bromoform, dibromochloromethane, and dibromomethane in the atmosphere. J. Geophys. Res. 110, D23309 (2005).

20. Anderson, P. S. \& Neff, W. D. Boundary layer physics over snow and ice. Atmos. Chem. Phys. 8, 3563-3582 (2008).

21. Granfors, A. et al. Biogenic halocarbons in young Arctic sea ice and frost flowers. Mar. Chem. 155, 124-134 (2013).

22. Sturges, W. T., Cota, G. F. \& Buckley, P. T. Vertical profiles of bromoform in snow, sea ice, and seawater in the Canadian Arctic. J. Geophys. Res. 102, 25073-25083 (1997).

23. Granfors, A., Karlsson, A., Mattsson, E., Smith, W. O. \& Abrahamsson, K. Contribution of sea ice in the Southern Ocean to the cycling of volatile halogenated organic compounds. Geophys. Res. Lett. 40, 3950-3955 (2013).

24. Wever, R., Tromp, M. G. M., Krenn, B. E., Marjani, A. \& Van Tol, M. Brominating activity of the seaweed Ascophyllum nodosum: impact on the biosphere. Environ. Sci. Tech. 25, 446-449 (1991).

25. Oum, K. W., Lakin, M. J. \& Finlayson-Pitts, B. J. Bromine activation in the troposphere by the dark reaction of $\mathrm{O} 3$ with seawater ice. Geophys. Res. Lett. 25, 3923-3926 (1998). 
26. Abbatt $\mathrm{J}$ et al. Release of gas-phase halogens by photolytic generation of $\mathrm{OH}$ in frozen halide-nitrate solutions: an active halogen formation mechanism? J. Phys. Chem. A 114, 6527-6533 (2010).

27. Artiglia, L. et al. A surface-stabilized ozonide triggers bromide oxidation at the aqueous solution-vapour interface. Nat. Commun. 8, 700 (2017).

28. Quack, B. \& Wallace, D. W. R. Air-sea flux of bromoform: controls, rates, and implications. Glob. Biogeochem. Cycles 17, doi: 10.1029/2002GB001890 (2003).

29. Junge, K., Eicken, H. \& Deming, J. W. Bacterial activity at -2 to $-20^{\circ} \mathrm{C}$ in Arctic wintertime sea ice. Appl. Environ. Microbiol. 70, 550-557 (2004).

30. Melnikov, I. A. Winter production of sea ice algae in the western Weddell Sea. J. Mar. Syst. 17, 195-205 (1998).

31. Jones, H. G., Pomeroy, J. W., Davies, T. D., Tranter, M. \& Marsh, P. CO2 in Arctic snow cover: landscape form, in-pack gas concentration gradients, and the implications for the estimation of gaseous fluxes. Hydrol. Process. 13, 2977-2989 (1999).

32. Albert, M. R. \& Shultz, E. F. Snow and firn properties and air-snow transport processes at Summit, Greenland. Atmos. Environ. 36, 2789-2797 (2002).

33. Ziska, F. et al. Global sea-to-air flux climatology for bromoform, dibromomethane and methyl iodide. Atmos. Chem. Phys. 13, 8915-8934 (2013).

34. Lamarque, J. F. et al. CAM-chem: description and evaluation of interactive atmospheric chemistry in the Community Earth System Model. Geosci. Model Dev. 5, 369-411 (2012).

35. Ordóñez, C. et al. Bromine and iodine chemistry in a global chemistry-climate model: description and evaluation of very short-lived oceanic sources. Atmos. Chem. Phys. 12, 1423-1447 (2012).

36. Fernandez, R. P., Salawitch, R. J., Kinnison, D. E., Lamarque, J. F. \& SaizLopez, A. Bromine partitioning in the tropical tropopause layer: implications for stratospheric injection. Atmos. Chem. Phys. 14, 13391-13410 (2014).

37. Frankenstein, G. \& Garner, R. Equations for determinating the brine volume of sea ice from -0.5 C to -22.9 C. J. Glaciol. 6, 943-944 (1967).

38. Wanninkhof, R. \& McGillis, W. R. A cubic relationship between air-sea $\mathrm{CO} 2$ exchange and wind speed. Geophys. Res. Lett. 26, 1889-1892 (1999).

39. Hayduk, W. \& Minhas, B. S. Correlations for prediction of molecular diffusivities in liquids. Can. J. Chem. Eng. 60, 295-299 (1982).

40. Moore, R. M., Geen, C. E. \& Tait, V. K. Determination of Henry's Law constants for a suite of naturally occurring halogenated methanes in seawater. Chemosphere 30, 1183-1191 (1995)

41. Saiz-Lopez, A. et al. Injection of iodine to the stratosphere. Geophys. Res. Lett. 42, 6852-6859 (2015).

42. Saiz-Lopez, A. et al. Iodine chemistry in the troposphere and its effect on ozone. Atmos. Chem. Phys. 14, 13119-13143 (2014).

43. Saiz-Lopez, A., Plane, J. M. C., Cuevas, C. A., Mahajan, A. S., Lamarque, J. F. \& Kinnison, D. E. Nighttime atmospheric chemistry of iodine. Atmos. Chem. Phys. 16, 15593-15604 (2016).

44. Prados-Roman, C., Cuevas, C. A., Fernandez, R. P., Kinnison, D. E., Lamarque, J. F. \& Saiz-Lopez, A. A negative feedback between anthropogenic ozone pollution and enhanced ocean emissions of iodine. Atmos. Chem. Phys. 15, 2215-2224 (2015).

45. Rienecker, M. M. et al. MERRA: NASA's modern-era retrospective analysis for research and applications. J. Clim. 24, 3624-3648 (2011).

\section{Acknowledgements}

This work was financed by the Swedish Research Council VR. The support by the Swedish Polar Secretariat is acknowledged. We thank Peter Lemke, Hans-Werner Jacobi, the captain, all crew members, and fellow scientists on board R.V Polarstern for assistance. K. Gårdfeldt, M. Nerentorp, and the biogeochemistry group are acknowledged for assistance. A special thanks to Gerhard Dieckmann for helping out with coring equipment. This work was also supported by the Consejo Superior de Investigaciones Científicas (CSIC) of Spain. The National Center for Atmospheric Research (NCAR) is funded by the National Science Foundation (NSF). Computing resources were provided by the Climate Simulation Laboratory at NCAR's Computational, and the Information Systems Laboratory (CISL), sponsored by the NSF, provided computing resources. The CESM project (which includes CAM-Chem) is supported by the NSF and the office of Science (BER) of the US Department of Energy. This study has received funding from the European Research Council Executive Agency under the European Union's Horizon 2020 Research and innovation programme (Project 'ERC-2016-COG 726349 CLIMAHAL')

\section{Author contributions}

K.A., A.G., and M.A. conceived the experiments, participated in the cruise, and sampled and interpreted all halocarbon data. C.A.C. and A.S.-L. performed the atmospheric modeling. All authors interpreted the results and contributed to writing the manuscript.

\section{Additional information}

Supplementary Information accompanies this paper at https://doi.org/10.1038/s41467018-07062-8.

Competing interests: The authors declare no competing interests.

Reprints and permission information is available online at http://npg.nature.com/ reprintsandpermissions/

Publisher's note: Springer Nature remains neutral with regard to jurisdictional claims in published maps and institutional affiliations.

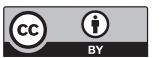

Open Access This article is licensed under a Creative Commons Attribution 4.0 International License, which permits use, sharing, adaptation, distribution and reproduction in any medium or format, as long as you give appropriate credit to the original author(s) and the source, provide a link to the Creative Commons license, and indicate if changes were made. The images or other third party material in this article are included in the article's Creative Commons license, unless indicated otherwise in a credit line to the material. If material is not included in the article's Creative Commons license and your intended use is not permitted by statutory regulation or exceeds the permitted use, you will need to obtain permission directly from the copyright holder. To view a copy of this license, visit http://creativecommons.org/ licenses/by/4.0/.

(C) The Author(s) 2018 